\title{
Influence of reactive sulfide (AVS) and supplementary food on Ag, Cd and Zn bioaccumulation in the marine polychaete Neanthes arenaceodentata
}

\author{
Jung-Suk Lee ${ }^{1}$, Byeong-Gweon Lee ${ }^{2,3, *}$, Hoon Yoo ${ }^{1}$, Chul-Hwan Koh ${ }^{1}$, Samuel N. Luoma ${ }^{2}$ \\ ${ }^{1}$ Ocean Science Program, School of Earth and Environmental Sciecnes, Seoul National University, Seoul 151-742, Korea \\ ${ }^{2}$ Water Resources Division, US Geological Survey, Mail Stop 465, 345 Middlefield Road, Menlo Park, California 94025, USA \\ ${ }^{3}$ Dept of Oceanography, Chonnam National University Gwangju 500-757, Korea
}

\begin{abstract}
A laboratory bioassay determined the relative contribution of various pathways of Ag, $\mathrm{Cd}$ and $\mathrm{Zn}$ bioaccumulation in the marine polychaete Neanthes arenaceodentata exposed to moderately contaminated sediments. Juvenile worms were exposed for $25 \mathrm{~d}$ to experimental sediments containing 5 different reactive sulfide (acid volatile sulfides, AVS) concentrations (1 to $30 \mu \mathrm{mol} \mathrm{g}^{-1}$ ), but with constant $\mathrm{Ag}, \mathrm{Cd}$, and $\mathrm{Zn}$ concentrations of $0.1,0.1$ and $7 \mu \mathrm{mol} \mathrm{g}{ }^{-1}$, respectively. The sediments were supplemented with contaminated food (TetraMin ${ }^{\circledR}$ ) containing 3 levels of Ag-Cd-Zn (uncontaminated, $1 \times$ or $5 \times$ metal concentrations in the contaminated sediment). The results suggest that bioaccumulation of $\mathrm{Ag}, \mathrm{Cd}$ and $\mathrm{Zn}$ in the worms occurred predominantly from ingestion of contaminated sediments and contaminated supplementary food. AVS or dissolved metals (in porewater and overlying water) had a minor effect on bioaccumulation of the 3 metals in most of the treatments. The contribution to uptake from the dissolved source was most important in the most oxic sediments, with maximum contributions of $8 \%$ for $\mathrm{Ag}$, 30\% for $\mathrm{Cd}$ and $20 \%$ for $\mathrm{Zn}$ bioaccumulation. Sediment bioassays where uncontaminated supplemental food is added could seriously underestimate metal exposures in an equilibrated system; $N$. arenaceodentata feeding on uncontaminated food would be exposed to 40-60\% less metal than if the food source was equilibrated (as occurs in nature). Overall, the results show that pathways of metal exposure are dynamically linked in contaminated sediments and shift as external geochemical characteristics and internal biological attributes vary.
\end{abstract}

KEY WORDS: Bioaccumulation $\cdot$ Metals $\cdot$ AVS $\cdot$ Dietary uptake

\section{INTRODUCTION}

Sediments constitute a concentrated reservoir of trace metals introduced via natural weathering processes and anthropogenic activities in most aquatic environments. Metals in sediments can be concentrated by benthic organisms and may have adverse effects at elevated levels (Long et al. 1995, Hornberger et al. 2000). The geochemical nature of the metal-sediment association and the relative distribution of metals between porewater and sediments could have considerable influence on the eventual fate and bioavailabililty

\footnotetext{
*Corresponding author. E-mail: bglee@usgs.gov
}

of metals to aquatic organisms (Luoma \& Bryan 1982, Di Toro et al. 1990, Lee \& Luoma 1998). Transfer of metals from sediments to benthic organisms may also be affected by biological attributes of animals such as feeding behaviors, life habits, reproductive cycles, growth, and size (Cain \& Luoma 1990, Arifin \& Bendall-Young 1997, Warren et al. 1998, B. G. Lee et al. 2000a)

Studies (e.g., Morse et al. 1987, Di Toro et al. 1990, Ankley et al. 1996) have recognized reactive sulfides (AVS, acid volatile sulfide) in sediments as a major factor controlling porewater metal chemistry. The AVS consists largely of amorphous iron sulfides and is typically extracted with cold weak acid (1 N HCl). Most of 
these studies show that the relative concentration of reactive metal (SEM, simultaneously extracted metals with AVS) and AVS, expressed as [SEM - AVS], determines porewater metal concentrations. An important conclusion of these studies is that metal bioavailability and toxicity to organisms in contaminated sediments are controlled by porewater metal concentrations and therefore are modulated by [SEM - AVS]. This AVS normalization approach has been proposed as a basis for sediment quality criteria for metals (Ankley et al. 1996). In contrast, another body of work has employed microcosm studies or biokinetic models (Luoma et al. 1992, Wang et al. 1996, Munger \& Hare 1997, Selck et al. 1998, B. G. Lee et al. 2000a) to demonstrate that uptake from ingestion of contaminated particles is a major route of metal bioaccumulation to various marine invertebrates. The conclusions about dominant uptake routes differ between these 2 bodies of work, but these differences are only beginning to be addressed (Luoma \& Fisher 1997, B. G. Lee et al. 2000a). Understanding which pathways affects exposure of aquatic organisms to metals under various environmental conditions and how this occurs is essential for environmental risk assessment of contaminated sediments.

Some chronic toxicity test procedures for contaminated sediments (e.g., animal growth and reproduction test) require use of supplementary food to stimulate the growth and reproduction of test organisms (John et al. 1990, Dillon et al. 1993, Murdoch et al. 1997, Anderson et al. 1998). For example, protocols measuring effects of contaminated sediments on growth and reproduction of the polychaete worm Neanthes arenaceodentata supply 6 to $24 \mathrm{mg}$ ind..$^{-1} \mathrm{wk}^{-1}$ supplementary food. Rarely, if ever, is supplementary food spiked with contaminants in a bioassay, although in nature food sources are contaminated in a contaminated system. A number of biological complications could arise from feeding test animals uncontaminated food in a bioassay, if diet is an important source of metal exposure. For example, exposure pathways could be altered. Selective feeding behavior has been observed for many benthic animals (Bayne et al. 1993, Arifin \& Bendall-Young 1997). Selective feeding of test animals on uncontaminated nutritious supplementary food may discourage ingestion of contaminated sediments and shift the exposure route to contaminants in the dissolved phase. Further, ingestion of nutritious food typically enhances the growth of an organism and may result in dilution of concentrations of contaminants by rapid growth of uncontaminated tissue mass. Yet, effects of supplementary food on exposure of animals to metals in contaminated sediments have not been addressed experimentally.

The primary objective of this study was to evaluate relative uptake routes of $\mathrm{Ag}, \mathrm{Cd}$ and $\mathrm{Zn}$ for the deposit- feeding polychaete Neanthes arenaceodentata, from moderately contaminated sediments with different reactive sulfide concentrations. Another goal was to evaluate the effect of contaminated supplementary food on bioaccumulation from contaminated sediments. A mass balance approach was employed to separate the routes of metal bioaccumulation in the worms. The uptake routes considered were natural background sediments, contaminated sediments, contaminated supplementary food and the dissolved phase (overlying water and porewater). N. arenaceodentata is an ubiquitous infaunal polychaete found in shallow marine and estuarine benthic habitats around world (Dillon et al. 1993). This worm was chosen since it has a short life cycle, is easy to culture in the laboratory and has been used in many metal toxicity and bioaccumulation experiments (Reish 1985, Mason et al. 1988, Pesch et al. 1995, B. G. Lee et al. 2000a). The 3 metals used in this study are characterized as highly toxic metals and have been studied for evaluation of AVS normalization approaches (e.g., Ankley et al. 1996, DeWitt et al. 1996, Berry et al. 1999).

\section{MATERIALS AND METHODS}

Experimental design. Neanthes arenaceodentata were exposed to sediments containing 5 different AVS concentrations ( 1 to $30 \mu \mathrm{mol} \mathrm{AVS} \mathrm{g}^{-1}$ ) with a constant level of $\mathrm{Ag}-\mathrm{Cd}-\mathrm{Zn}$ spiked into the sediment $(0.1,0.1$, and $7 \mu \mathrm{mol} \mathrm{g}{ }^{-1}$, respectively) (Fig. 1). The supplementary food was a commercial aquarium fish food $\left(\right.$ TetraMin $^{\circledR}$ ) and was added either uncontaminated $\left(\mathrm{F}_{0 \times}\right)$ or spiked with $\mathrm{Ag}-\mathrm{Cd}-\mathrm{Zn}$ at concentrations $1 \times$ $\left(F_{1 \times}\right)$ or $5 \times\left(F_{5 \times}\right)$ the metal concentrations of the spiked sediments (Fig. 1). Two groups of worms were exposed to unspiked sediments with 1 or $20 \mu \mathrm{mol}$ AVS g ${ }^{-1}$ (control-oxic and control-anoxic, respectively) and fed unspiked food. An additional group of worms were incubated in the unspiked sediment $\left(10 \mu \mathrm{mol} \mathrm{AVS} \mathrm{g}{ }^{-1}\right)$ but fed $\mathrm{F}_{5 \times}$ food (control- $\mathrm{F}_{5 \times}$ ).

Sediment and supplementary food preparations. The experimental sediment was obtained from a mud flat near Palo Alto, San Francisco Bay, USA. Mud flat sediment naturally high in AVS (ca $40 \mu \mathrm{mol} \mathrm{g}{ }^{-1}$ ) was collected, following removal of the surface oxic layer, screened through $1 \mathrm{~mm}$ nylon mesh at the site and transferred to laboratory. No attempt was made to enumerate the organisms present in the sediments that passed $1 \mathrm{~mm}$ screen. Mean particle size was $6.3 \Phi$ and mean sand, silt and clay content, analyzed by the pipetting method (Folk 1954), were 0.5, 75, and $24.5 \%$, respectively. The loss on ignition (LOI, at $450^{\circ} \mathrm{C}$ for $5 \mathrm{~h}$ ) was $6.8 \pm 0.5 \%$ (mean \pm standard deviation).

The experimental containers and glass-ware used for sediment handling, chemical analysis and sample 
Metal-Spiked Sediment (Ag: 0.1; Cd: 0.1; Zn: $7 \mu \mathrm{mol} / \mathrm{g}$ )
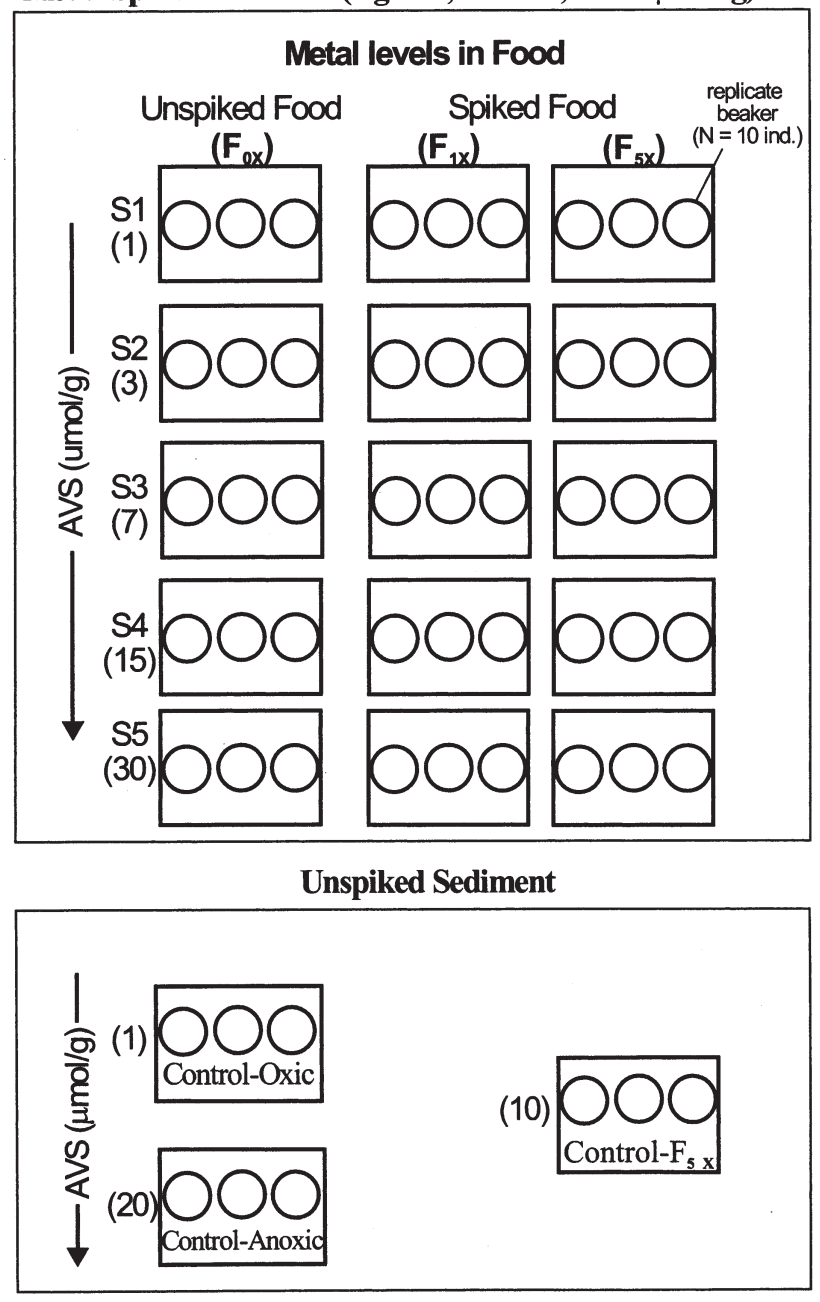

Fig. 1. Schematic diagram of experimental treatments. Metal spiked sediment contained $0.1 \mu \mathrm{mol} \mathrm{Ag} \mathrm{g}{ }^{-1}, 0.1 \mu \mathrm{mol} \mathrm{Cd} \mathrm{g}{ }^{-1}$, and $7 \mu \mathrm{mol} \mathrm{Zn} \mathrm{g}{ }^{-1}$. None of the 3 control sediments were spiked with metals. Nominal AVS concentrations in experimental sediments increased from 1 (S1) to $30 \mathrm{\mu mol} \mathrm{g}^{-1}$ (S5). The worms were fed either uncontaminated food $\left(\mathrm{F}_{0 \times}\right)$, food contaminated with $1 \times$, or $5 \times$ sediment metal concentrations $\left(\mathrm{F}_{1 \times}\right.$ or $\left.\mathrm{F}_{5 \times}\right)$

storage were acid washed, followed by soaking in deoxygenated Milli-Q water for $1 \mathrm{wk}$. The sediment samples were handled under a glove bag filled with $\mathrm{N}_{2}$ gas. In the laboratory, a portion of the collected sediment was spiked with metals and manipulated for appropriate AVS levels following a protocol established by Lee et al. (2000b). Briefly, the sediment was mixed with the equal volume of deoxygenated seawater (30 psu) that had been previously spiked with the metal stock solutions prepared with reagent grade $\mathrm{AgNO}_{3}, \mathrm{CdCl}_{2}$ and $\mathrm{ZnCl}_{2}$. Following $1 \mathrm{wk}$ of sedimentmetal equilibration, half of the metal-spiked sediment was oxidized by bubbling continuously with air for $1 \mathrm{wk}$ and the remaining anoxic metal-spiked sediment was kept in $\mathrm{N}_{2}$-atmosphere. Aeration of metal-spiked anoxic sediment for 1 week reduced the AVS concentration from ca 40 to ca $1 \mu \mathrm{mol} \mathrm{g}{ }^{-1}$. The remaining uncontaminated sediments were also manipulated to obtain uncontaminated anoxic and oxic sediments for the control samples (control-anoxic, control-oxic, and control- $\left.F_{5 \times}\right)$. The AVS concentration of uncontaminated anoxic sediment declined from ca 40 to $\mathrm{ca}$ $20 \mu \mathrm{mol} \mathrm{g}^{-1}$ under $\mathrm{N}_{2}$ atmosphere, while the metal spiked sediment maintained its initial AVS concentration. A similar phenomenon was observed in other studies (Liber et al. 1996, B. G. Lee et al. 2000b) and was explained by faster oxidation rate of iron sulfides in uncontaminated sediments than other metal sulfides formed in metal-spiked sediments.

The oxidized and anoxic sediments were mixed at appropriate ratios to achieve five nominal AVS levels (1 to $30 \mu \mathrm{mol} \mathrm{g}{ }^{-1}$ ). Following the AVS manipulation, $300 \mathrm{ml}$ of sediment slurry was transferred to each of 3 replicate $1 \mathrm{l}$ glass beakers for each treatment (Fig. 1). A total of $800 \mathrm{ml}$ of seawater (30 psu) was added $2 \mathrm{~d}$ after sediment transfer and replaced a day prior to animal introduction. The sediments were allowed to consolidate for $9 \mathrm{~d}$ prior to animal introduction. The sediment volume was reduced to ca $200 \mathrm{ml}$ during this time. Two replicate subsamples of sediments were collected using syringes at the mid sediment depth at $9 \mathrm{~d}$ before $(t=-9 \mathrm{~d})$ and the beginning of animal incubation $(t=0)$ for geochemical characterization.

Metal contaminated food particles were prepared by suspending ground TetraMin ${ }^{\circledR}(<250 \mu \mathrm{m})$ into autoclaved deionized water containing appropriate levels of Ag-Cd-Zn (Fig. 1). Deionized water was used to facilitate faster dissolution of metal salts. The metalfood mixture was equilibrated for $1 \mathrm{wk}$ at $2^{\circ} \mathrm{C}$ and shaken several times daily. Then the metal adsorbed particles were resuspended in seawater (30 psu) for $1 \mathrm{~d}$ at $2{ }^{\circ} \mathrm{C}$ to minimize desorption of metals during feeding processes. The settled particles were freeze-dried, ground finely again $(<250 \mu \mathrm{m})$ before use, and analyzed for metal concentrations (Table 1).

Bioassay procedures. Laboratory cultured juvenile polychaetes, Neanthes arenaceodentata (2 wk, postemergent; obtained from Dr Reish, California State Univ., Long Beach, USA), were acclimated for $3 \mathrm{~d}$ at $20^{\circ} \mathrm{C}$ in $30 \mathrm{psu}$ seawater. Culturing and testing protocols for lethal and sublethal toxicity tests are reported elsewhere (Reish 1980, Dillon et al. 1993, Anderson et al. 1998). Following acclimation, the worms were divided into groups of 10 individuals and introduced randomly into each experimental sediment. Each treatment had 3 replicate beakers (Fig. 1). During the $25 \mathrm{~d}$ incubation of the test animals, overlying seawater was continuously aerated and replaced (ca $60 \%$ ) every $2 \mathrm{~d}$. Test chambers were illuminated with a light:dark cy- 
Table 1. Mean and standard deviation (SD) of $\mathrm{Ag}, \mathrm{Cd}$, and $\mathrm{Zn}$ concentrations in supplementary food $(n=3) . F_{0 \times}$ is unspiked supplementary food; $F_{1 \times}$ and $F_{5 \times}$ are supplementary foods that are $1 \times$ and $5 \times$ the metal concentrations in spiked sediments, respectively. -: unknown

\begin{tabular}{|c|c|c|c|c|c|c|c|c|c|}
\hline \multirow[t]{3}{*}{ Treatment } & \multicolumn{3}{|c|}{$\mathrm{Ag}\left(\mu \mathrm{mol} \mathrm{g} \mathrm{g}^{-1}\right)$} & \multicolumn{3}{|c|}{$\mathrm{Cd}\left(\mu \mathrm{mol} \mathrm{g}{ }^{-1}\right)$} & \multicolumn{3}{|c|}{$\mathrm{Zn}\left(\mu \mathrm{mol} \mathrm{g}{ }^{-1}\right)$} \\
\hline & \multirow[t]{2}{*}{ Nominal } & \multicolumn{2}{|c|}{ Measured } & \multirow[t]{2}{*}{ Nominal } & \multicolumn{2}{|c|}{ Measured } & \multirow[t]{2}{*}{ Nominal } & \multicolumn{2}{|c|}{ Measured } \\
\hline & & Mean & $\mathrm{SD}$ & & Mean & $\mathrm{SD}$ & & Mean & $\mathrm{SD}$ \\
\hline $\mathrm{F}_{0 x}$ & - & 0.004 & 0.001 & - & 0.003 & 0.000 & - & 1.4 & 0.1 \\
\hline$F_{1 x}$ & 0.10 & 0.09 & 0.02 & 0.10 & 0.10 & 0.00 & 7 & 11 & 2 \\
\hline $\mathrm{F}_{5 x}$ & 0.50 & 0.43 & 0.15 & 0.50 & 0.31 & 0.01 & 35 & 40 & 8 \\
\hline
\end{tabular}

concentrated hot nitric acid following a method described by Brown \& Luoma (1995). Procedure blanks and NBS oyster tissue (SRM 1566a) were accompanied at each digestion for quality control and assurance. Mean recoveries for $\mathrm{Ag}, \mathrm{Cd}$ and $\mathrm{Zn}$ of SRM were $90 \pm 2,95 \pm 1$ and $91 \pm 1 \%$, respectively. Metal concentrations in tissue digest, SEM, porewater, and overlying water samples were determined with ICAP-AES and/or GF-AAS.

cles of 14:10 H L:D. During the incubation period, the worms were fed 10 times ( $7 \mathrm{mg}$ ind. ${ }^{-1}$ for each time) with the previously prepared TetraMin ${ }^{\circledR} 6 \mathrm{~h}$ before changing overlying water. The worms were fed every $4 \mathrm{~d}$ for initial $12 \mathrm{~d}$ of incubation and every $2 \mathrm{~d}$ thereafter considering growth of animals. Overlying water quality was monitored 1 to 2 times a week. Temperature, salinity, $\mathrm{pH}$ and dissolved oxygen (mean $\pm \mathrm{SD}$ ) were $20 \pm 1^{\circ} \mathrm{C}, 30 \pm 1 \mathrm{psu}, 8.02 \pm 0.05$ and $6.8 \pm 1.1 \mathrm{mg} \mathrm{l}^{-1}$, respectively. Additionally, overlying waters at $5 \mathrm{~cm}$ above sediments were sampled $1 \mathrm{~d}$ prior to water change and were acidified ( $\mathrm{pH}=\mathrm{ca} 2$ ) for later metal analysis.

Following 25 d incubation with animals, subsamples of sediment from the surface oxidized layer ( 0 to $5 \mathrm{~mm}$ ) and the deep sediment (5 to $20 \mathrm{~mm}$ ) were collected from each experimental beaker. The sediment samples from 3 replicate beakers for each treatment were pooled into 1 sample and kept at $4^{\circ} \mathrm{C}$ refrigerator for later chemical analyses. The remaining sediment in the beakers was sieved with a $1 \mathrm{~mm}$ nylon screen to collect worms. There was no significant difference in survival rates $(94 \pm 7 \%)$ of the worms among treatments. Worms were allowed to depurate in $0.22 \mu \mathrm{m}$ filtered seawater for $24 \mathrm{~h}$. Both visual observation and tissue aluminum concentration suggested that worms depurated most of the ingested particles during this time. Then the worms from each replicate beaker were pooled into 1 composite sample (3 replicates, composed of ca 10 worms treatment ${ }^{-1}$ ), freeze-dried, and dry weight was determined. The mean dry weight of worm increased ca 20 times from $0.87 \pm 0.15$ to $15.8 \pm$ $1.7 \mathrm{mg}$ ind..$^{-1}$ during the $25 \mathrm{~d}$ incubation periods.

Analytical procedure. AVS, SEM, overlying water and porewater analyses were done within $1 \mathrm{wk}$ of sample collection. Two replicate sediments from each treatment were analyzed for AVS and SEM at each sampling time ( $t=-9,0$ and 25$)$ except for surface sediments at $t=25$ which had no replication. Most dissolved metals in porewater and overlying water were analyzed without replication. The detailed analytical protocols are described elsewhere (B. G. Lee et al. $2000 b)$. Freeze-dried worm samples were digested in
Porewater and overlying water samples were diluted at least 5 times with $0.1 \mathrm{~N}$ nitric acid (Ultrex ${ }^{\circledR}$ ) to mitigate chloride interference before direct analysis.

Data analysis. AVS and SEM concentrations, and [SEM - AVS] for 3 metals from all treatments were analyzed using multi-way analysis of variance (ANOVA) to test the effect of initial AVS level, incubation time, sediment depth, and metal levels in supplementary food. Statistical significance was set at $\alpha=0.05$, unless otherwise noted. Limited statistical analyses were done for the dissolved metal data (overlying water and porewater) due to lack of replication and detection limits. Tissue metal concentrations in worms were analyzed by 3 -way ANOVA to test the effects of [SEM - AVS], and metal concentrations in food and sediments. When a significant effect was found from ANOVA analysis, Tukey's multiple comparison test was used to determine differences between specific treatments. Dry weight based concentrations were used for all sediment and tissue data. Statistica ${ }^{\circledR}$ was used for all statistical analysis.

When [SEM - AVS] is calculated for a certain metal, all metals with greater affinity for AVS than the metal of concern should be considered as SEM (Ankley et al. 1996, B. G. Lee et al. 2000b). This practice is required to account for binding of other metals with AVS that might bind as strongly or stronger than the metal of concern. In this paper, for example, when [SEM - AVS] is calculated for $\mathrm{Cd}$, the molar sum of extracted $\mathrm{Ag}, \mathrm{Cu}$, and $\mathrm{Pb}$ concentrations, in addition to concentrations of extracted Cd, represent SEM. Therefore, the [SEM - AVS] values for $\mathrm{Cd}$ in specific sediment is calculated by subtracting concentrations of AVS from the sum of $\mathrm{Ag}, \mathrm{Cu}$, $\mathrm{Pb}$ and $\mathrm{Cd}$ concentrations determined for the sediment. The sum of mean $\mathrm{Cu}$ and $\mathrm{Pb}$ SEM was $0.51 \mu \mathrm{mol} \mathrm{g}^{-1}$.

\section{RESULTS}

\section{Sediment geochemistry}

A range of AVS concentrations were successfully achieved by the direct oxidation and mixing method (Table 2). AVS concentrations in the deep sediments 


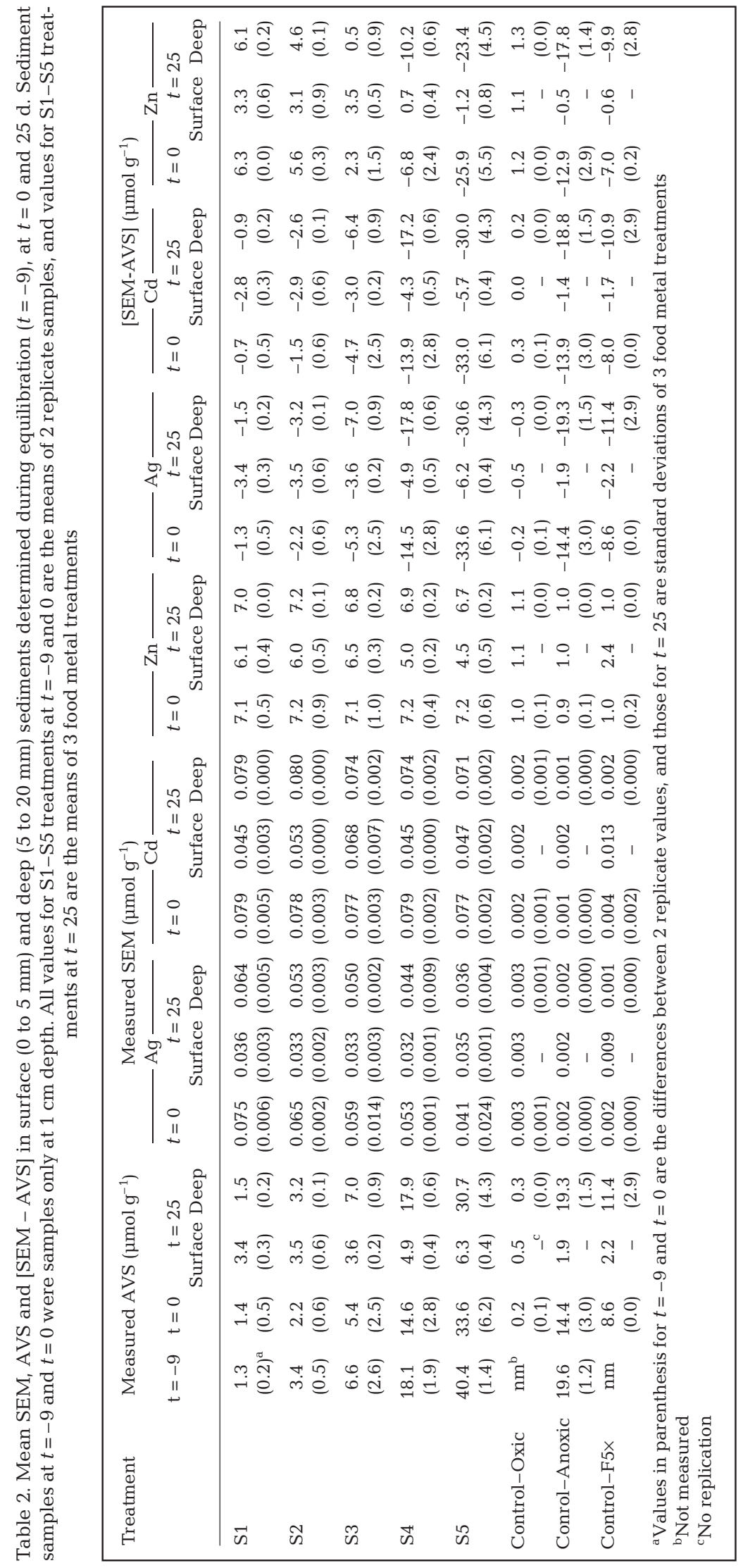

(0.5 to $2 \mathrm{~cm}$ ) did not change significantly ( $p>0.05$ ) during $25 \mathrm{~d}$ incubation time. Following $25 \mathrm{~d}$ incubation, AVS in the surface decreased in the sediments that were initially anoxic (control-anoxic, control- $\mathrm{F}_{5 \times}$ and S4-5 treatments), but increased in the oxic sediments (controloxic and S1-2 treatments) $(\mathrm{p}<0.05)$, probably due to a combination of bioturbation by the test organism Neanthes arenaceodentata, oxidation by aerated overlying water and decomposition of supplementary foods at the sediment surface (Table 2). Concentrations of AVS were similar in the sediments with 3 different food treatments $(p>0.05)$. Therefore, mean AVS concentrations of these 3 food treatments are reported and used for the [SEM - AVS] calculation (Table 2). The organic matter content (determined as LOI) was changed little $(p>0.05)$ in the deep sediments $(6.6 \pm 0.4 \%)$, but increased significantly $(\mathrm{p}<0.001)$ in the surface $(8.1 \pm 0.5 \%)$ from the initial value $(6.8 \pm 0.6 \%)$ probably due to addition of supplementary food.

The SEM concentrations in the surface of the contaminated sediments declined significantly ( $<0.01$ ) over $25 \mathrm{~d}$ (Table 1 ). SEM concentrations of $\mathrm{Cd}$ and $\mathrm{Zn}$ in the deep sediments varied little as AVS concentration increased from S1 to S5 or with incubation time $(p>0.05)$. Extractable Ag decreased significantly with AVS $(p<0.001)$ and incubation time $(p<$ 0.05 ). Addition of supplementary foods containing 3 different levels of metals had insignificant $(p>0.05)$ effects on SEM concentrations in the metal spiked sediments. Therefore, the mean SEM values from these treatments are reported and used for the [SEM - AVS] calculation (Table 1). By design, [SEM AVS] related inversely to AVS levels. The [SEM - AVS] of Ag and Cd for all the treatments, with the exception of controloxic treatment, were $<0$. The [SEM AVS] of Zn were mostly $>0$, except for some deep sediments with high AVS (S4 and 5) and unspiked sediments with high AVS (control-anoxic, control- $\mathrm{F}_{5 \times}$ ).

Mean $\mathrm{Cd}$ and $\mathrm{Zn}$ concentrations in porewater and overlying water increased with [SEM-AVS], suggesting that AVS influenced dissolved metal concentra- 
tions (Fig. 2). Dissolved Ag was not detectable by GFAAS $(<0.01 \mu \mathrm{M})$ in all the treatments. The concentrations of $\mathrm{Cd}$ and $\mathrm{Zn}$ in porewater increased sharply near $[\mathrm{SEM}-\mathrm{AVS}]=0$, while those in overlying water gradually increased with [SEM - AVS] (Fig. 2). At the beginning of incubation $(t=0)$, porewater $\mathrm{Cd}$ ranged from $0.034 \pm 0.021$ to $<0.001 \mu \mathrm{M}$ and porewater $\mathrm{Zn}$ from $7.5 \pm 3.6$ to $0.3 \pm 0.2 \mu \mathrm{M}$, from most oxic (S1) to anoxic (S5) sediments ( $\mathrm{n}=3$ for all). At the completion of incubation, porewater $\mathrm{Cd}$ in all treatments except $\mathrm{S} 1$ $(0.003 \pm 0.004 \mu \mathrm{M})$ were $<0.001 \mu \mathrm{M}$ and mean porewater $\mathrm{Zn}$ decreased to concentrations that were 14 to $67 \%$ of the initial values. Metal levels in the supplementary food had an insignificant effect ( $p>0.05)$ on porewater $\mathrm{Cd}$ and $\mathrm{Zn}$ concentrations. Similarly, the mean overlying water metals, measured 6 times, de-
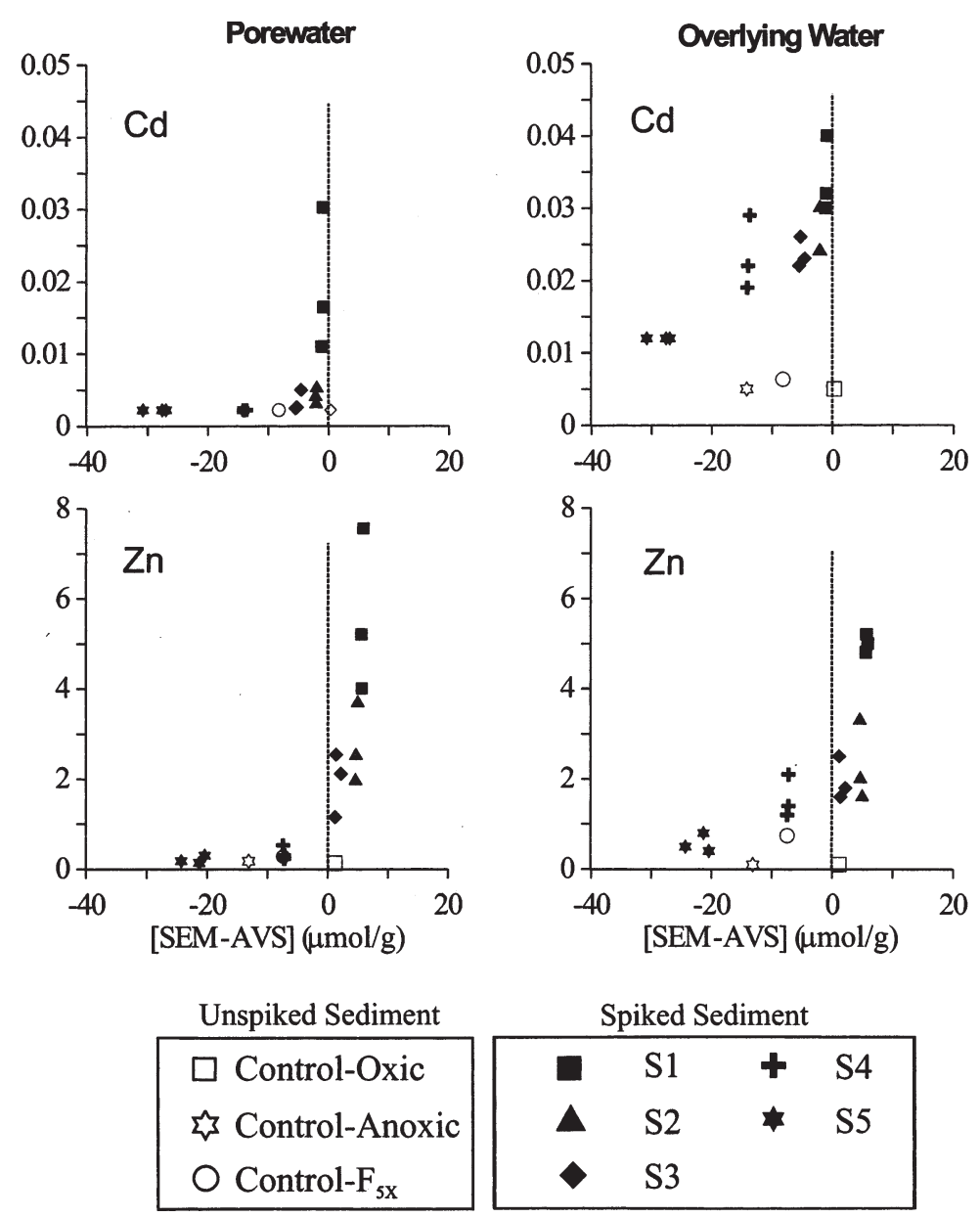

Fig. 2. Neanthes arenaceodentata. Time-averaged dissolved Cd and $\mathrm{Zn}$ concentrations in porewater ( $t=0$ and $t=25)$ and overlying water $(t=0,4,9,17,21$ and 25) with relation to [SEM - AVS] determined for unspiked (open symbols) or metal-spiked (filled symbols) sediments. The 3 replicate symbols represent treatments with 3 different metal levels in foods. Nominal AVS concentration increased from S1 $\left(1 \mathrm{mmol} \mathrm{g}^{-1}\right)$ to S5 $\left(30 \mu \mathrm{mol} \mathrm{g}^{-1}\right)$. Depth and time averaged [SEM - AVS] values were used here. Dotted vertical line: $[\mathrm{SEM}-\mathrm{AVS}]=0$ creased from S1 $(0.036 \pm 0.005 \mu \mathrm{M}$ Cd and $5.0 \pm 0.2 \mu \mathrm{M}$ $\mathrm{Zn})$ to $\mathrm{S} 5(0.012 \pm 0.000 \mathrm{Cd}$ and $0.60 \pm 0.20 \mu \mathrm{M} \mathrm{Zn})$. Overlying water $\mathrm{Cd}$ and $\mathrm{Zn}$ had significant $(\mathrm{p}<0.01)$ temporal variations but without consistent trends. The treatments with the most contaminated food $\left(\mathrm{F}_{5 \times}\right)$ had $0.006 \pm 0.004 \mu \mathrm{M}$ and $0.69 \pm 0.80 \mu \mathrm{M}$ more overlying water $\mathrm{Cd}$ and $\mathrm{Zn}$, respectively, than those with uncontaminated food. These results suggest that some $\mathrm{Cd}$ and $\mathrm{Zn}$ adsorbed to food particles were released during feeding processes.

\section{Metal bioaccumulation}

Worms exposed to metal-spiked sediment $\left(\mathrm{F}_{0 \times}\right)$ accumulated more than $3 \times$ the $\mathrm{Ag}$ and $\mathrm{Cd}$ found in the control worms (control-oxic and controlanoxic), although [SEM-AVS] was <0 (Figs. 3 \& 4). Worms fed contaminated supplementary food $\left(\mathrm{F}_{1 \times}\right.$ or $\left.\mathrm{F}_{5 \times}\right)$ accumulated significantly more $(\mathrm{p}<0.001) \mathrm{Ag}$ and $\mathrm{Cd}$ than worms fed uncontaminated food $\left(F_{0 \times}\right)$. For example, the worms fed supplementary food spiked with $5 \times$ sediment metal concentrations $\left(\mathrm{F}_{5 \times}\right)$ had $3.4 \times \mathrm{Ag}$ and $2.3 \times \mathrm{Cd}$ than worms fed uncontaminated food $\left(\mathrm{F}_{0 \times}\right)$. The mass of metal added as supplementary food at $\mathrm{F}_{5 \times}$ treatment was only about $3 \%$ of the total mass in contaminated sediments. The worms fed $5 \times$ metal contaminated food, but in unspiked sediment, had ca 10× Ag and Cd than the control worms (Figs. 3 \& 4). Tissue Ag and $\mathrm{Cd}$ in the worms treated with the various food metal levels was not ( $p>0.05$ ) influenced by [SEM - AVS], except for tissue $\mathrm{Ag}$ in the $\mathrm{F}_{5 \times}$ which decreased with [SEM - AVS].

In all treatments (and controls), worms contained ca $3 \mu \mathrm{mol} \mathrm{Zn} \mathrm{g}{ }^{-1}$ (Figs. 3 \& 4). Tissue $\mathrm{Zn}$ concentrations were not different $(p>0.05)$ from the controls in any treatment except the low AVS treatment (S1). There, [SEM - AVS] was considerably higher than other treatments and tissue $\mathrm{Zn}$ was ca $30 \%$ greater than in control worms (Figs. 3 \& 4). Yet the differences of Zn concentrations in porewater between S1 and S5, and in foods between uncontaminated and most contaminated, were $>20$ times. Regulation of $\mathrm{Zn}$ in the various animals, especially in polychaetes, has long been reported (Bryan \& Langston 1992). In the present experiments, Neanthes arenaceodentata seemed to regulate Zn. 

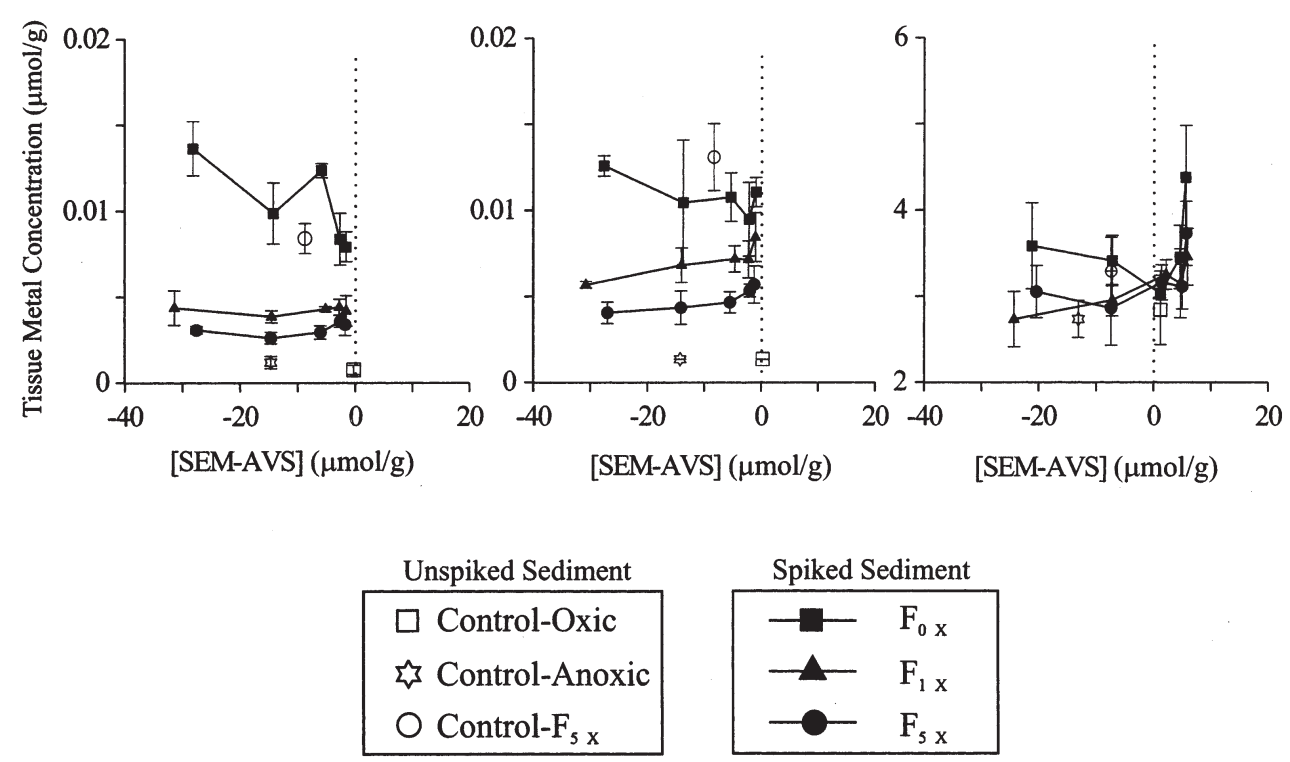

Fig. 3. Neanthes arenaceodentata. Mean and standard deviations (error bar) of tissue Ag, Cd and Zn concentrations in N. arenaceodentata $(\mathrm{n}=3$ ) from unspiked (open symbols) or metal-spiked (filled symbols) sediments with relation to [SEM - AVS]. Depth averaged [SEM - AVS] values were used here. The worms were fed either uncontaminated food $\left(\mathrm{F}_{0 \times}\right)$, food contaminated with $1 \times$ or $5 \times$ sediment metal concentrations $\left(\mathrm{F}_{1 \times}\right.$ or $\left.\mathrm{F}_{5 \times}\right)$. The dotted vertical line represents $[\mathrm{SEM}-\mathrm{AVS}]=0$

\section{Mass balance approach}

The experimental design allowed determination of the relative contribution of metals from different sources to bioaccumulation in the worms, using a mass balance approach, as follows,

$$
[M]_{\text {Tissue }}=[M]_{\text {Back }}+[M]_{\text {Sed }}+[M]_{\text {Diss }}+[M]_{\text {Food }}
$$

where $[M]_{\text {Tissue }}$ is tissue metal concentrations in Neanthes arenaceodentata following $25 \mathrm{~d}$ exposure, $[M]_{\mathrm{Back}}$ is tissue metal obtained from natural background sediments and uncontaminated food, $[M]_{\text {Sed }}$ is from ingestion of contaminated sediments, $[M]_{\text {Diss }}$ is from dissolved source (overlying water and porewater), and $[M]_{\text {Food }}$ is from ingestion of contaminated supplementary food $\left(\mathrm{F}_{1 \times}\right.$ or $\left.\mathrm{F}_{5 \times}\right)$. The mean tissue metals in the
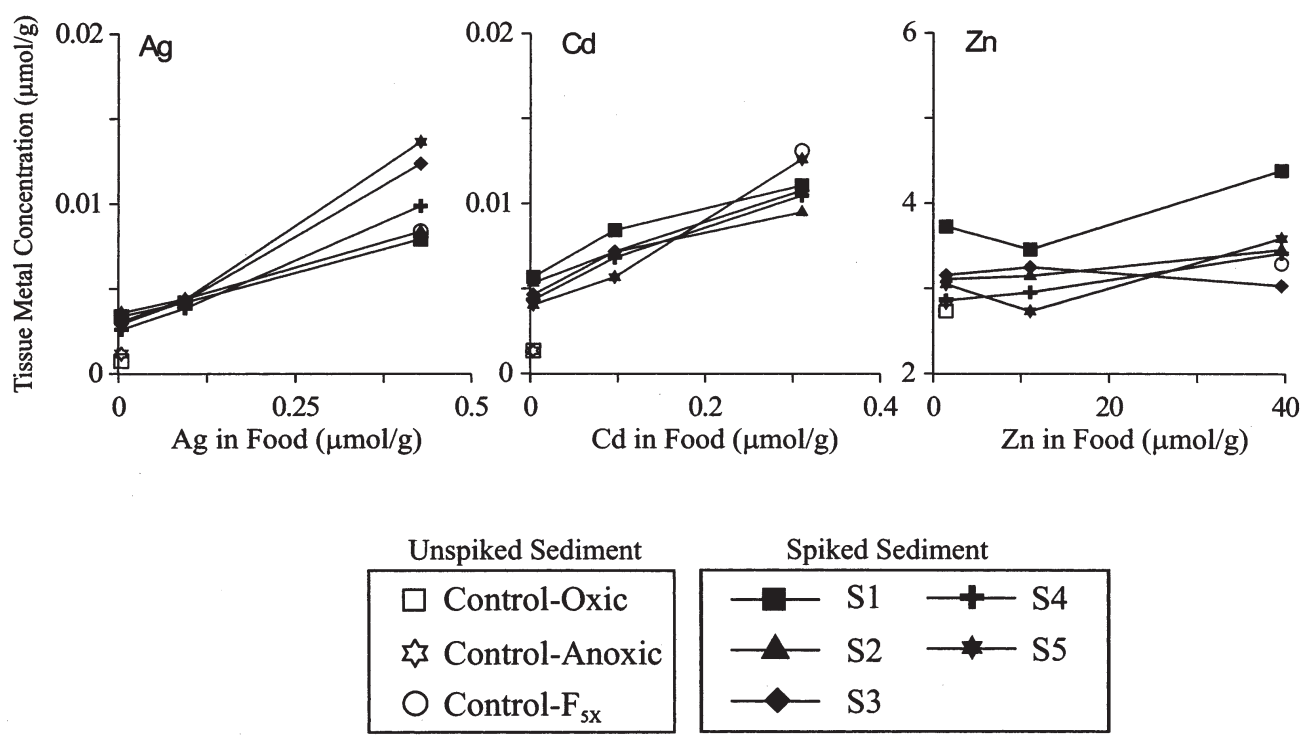

Fig. 4. Neanthes arenaceodentata. Mean tissue Ag, Cd and Zn concentrations in N. arenaceodentata from unspiked (open symbols) or metal-spiked (filled symbols) sediments with relation to metal concentrations in supplementary food. Nominal AVS concentration increased from S1 $\left(1 \mu \mathrm{mol} \mathrm{g}^{-1}\right)$ to S5 $\left(30 \mu \mathrm{mol} \mathrm{g}{ }^{-1}\right)$ 
control worms (control-anoxic and control-oxic) were considered to be background $\left([M]_{\text {Back }}\right)$, because these worms were exposed to uncontaminated sediment and food. $[M]_{\text {Sed }}$ was calculated by subtracting $[M]_{\text {Back }}$ from the tissue metals in the worms fed uncontaminated food $\left(\mathrm{F}_{0 \times}\right)$ in spiked anoxic sediment (S5) where dis- solved metal concentrations (porewater and overlying water) were minimal. It was assumed that bioavailability of metals from sediment particles having different AVS concentrations were not different (see 'Discussion'). The difference between tissue metals in S1 and S5 treatments for a given food metal level was assumed to result from the difference in dissolved metal concentrations between 2 treatments. Time-averaged dissolved $\mathrm{Cd}$ and Zn concentrations in porewater and overlying water in S5 were significantly lower than those in $\mathrm{S} 1$, or close to detection limits (Fig. 2). Therefore, contributions of dissolved metals in S5 to bioaccumulation were assumed to be none. Therefore, the maximum contribution of $[M]_{\text {Diss }}$ was calculated by subtracting the mean tissue metal concentrations in the most anoxic sediment (S5) from those in the most oxic sediment (S1). $[M]_{\text {Food }}$ was calculated by the difference of the mean tissue metal concentration in the unspiked food treatment $\left(\mathrm{F}_{0 \mathrm{x}}\right)$ and in the worms exposed to spiked food treatment $\left(\mathrm{F}_{1 \mathrm{X}}\right.$ or $\left.\mathrm{F}_{5 \mathrm{X}}\right)$. Efflux or growth dilution of tissue metals was assumed to be similar for all the treatments and therefore was not considered in this mass balance approach.

The mass balance results showed that the ingestion of contaminated sediment and food was responsible for 50 to $90 \%$ of $\mathrm{Ag}$ and $\mathrm{Cd}$ bioaccumulation in the worms (Fig. 5). The contribution of the dissolved source became negligible and contaminated particles became progressively more important when animals were fed supplementary contaminated food. Metals from the dissolved phase contributed only up to ca $8 \%$ of $\mathrm{Ag}$ and ca $30 \%$ of $\mathrm{Cd}$ bioaccumulation from the most oxidized sediments (S1) (as shown in Fig. 5). When animals were exposed to more anoxic sediments than S1, the contribution from the dissolved source was less than shown in Fig. 5 (data not shown). It was questionable whether any bioaccumulation of Zn occurred except in the most oxic sediment. There, the contribution of dissolved source ranged from 13 to $15 \%$ of tissue $\mathrm{Zn}$.
Fig. 5. Neanthes arenaceodentata. Estimated tissue metal concentrations in $N$. arenaceodentata from most oxidized sediments (S1) derived from the mass balance equation: $[M]_{\text {Tissue }}=[M]_{\text {Back }}+[M]_{\text {Sed }}+[M]_{\text {Diss }}+[M]_{\text {Food, }}$ where $[M]_{\text {Tissue }}$ is tissue metal concentrations in the worm, $[M]_{\text {Back }}$ is tissue metal obtained from natural background sediments and uncontaminated food, $[M]_{\text {Sed }}$ is from ingestion of contaminated sediments, $[M]_{\text {Diss }}$ is from dissolved source (overlying water and porewater), and $[M]_{\text {Food }}$ is from ingestion of contaminated supplementary food $\left(\mathrm{F}_{1 \times}\right.$ or $\left.\mathrm{F}_{5 \times}\right)$. Tissue metal concentrations are represented as (A) \% contribution from 4 different sources, or (B) normalized to tissue metal concentrations in the $\mathrm{F}_{0 \times}$ treatment 


\section{DISCUSSION}

This study examined the relative contribution of various uptake pathways for $\mathrm{Ag}, \mathrm{Cd}$, and $\mathrm{Zn}$ bioaccumulation in a deposit-feeding polychaete from moderately contaminated sediments. The overall results suggest that ingestion of contaminated sediments and supplementary food were responsible for most of metal bioaccumulation in the test worm. AVS clearly influenced partitioning of metals in both porewater and overlying water as shown by many previous studies (Hare et al. 1994, Berry et al. 1996, B. G. Lee et al. 2000b). However, neither AVS nor dissolved metal had a great influence on metal bioaccumulation. The contribution of dissolved metals decreased when the more anoxic sediments were considered. These findings are consistent with other studies, emphasizing that benthic organisms bioaccumulate metals in contaminated sediments from ingestion of various food particles, and biological attributes of animals modify exposure conditions (Wang et al. 1996, Lee \& Luoma 1998, Selck et al. 1998, B. G. Lee et al. 2000a,b).

Our results are contradictory to earlier studies (Kemp \& Swartz 1988, Di Toro et al. 1990, Berry et al. 1996) that concluded AVS or porewater have a major role in controlling metal bioavailability to aquatic organisms in contaminated sediment. The discrepancy could be attributable partly to the differences in experimental protocols between the studies. The earlier studies tested acute toxicity of organisms (typically, a $10 \mathrm{~d}$ mortality test) exposed to sediments spiked with extremely high metal concentrations. These experimental protocols accentuated exposure of organisms to the dissolved phase. Use of high metal concentration was necessary in these experiments because porewater metal concentration was controlled by spiking metals to the sediment containing a high, constant AVS concentration. In some of the studies, precipitates of metal salts formed on the surface sediments (e.g., Di Toro et al. 1990, Berry et al. 1996). Use of high metal concentrations can shift the partitioning of metals from particles to porewater, lowering the partitioning coefficient $\left(K_{\mathrm{d}}\right.$; Luoma \& Fisher 1997, J. S. Lee et al. 2000). $K_{\mathrm{d}}$ values determined in the present study were generally $>10^{4}$ for $\mathrm{Ag}$ and $\mathrm{Cd}$, and $>2 \times 10^{3}$ for $\mathrm{Zn}$, much greater than values observed in some of the previous studies (see also J. S. Lee et al. 2000).

Metal spiking protocols affect the partition coefficient in several ways. Adsorption isotherms (e.g., Langmuir isotherm) can be non-linear at high adsorbate (metal) concentrations (Bourg 1987, Hassan et al. 1996). For example, Hassan et al. (1996) reported in adsorption of 5 metals to various sediments for $24 \mathrm{~h}$ that partitioning coefficients decreased with increased metal concentrations even when concentrations in the metal mixture were relatively low (15 to $700 \mu \mathrm{g}^{-1}$ ). In addition, a short metal-sediment equilibration time is typically employed in many studies, which can enhance partitioning of metals to porewater relative to sediment particles (J. S. Lee et al. 2000). Partitioning coefficients typically decrease as the metal-sediment equilibration time increases (Di Toro et al. 1996, Sibley et al. 1996, Leonard et al. 1999). For example, Sibley et al. (1996) reported that porewater Zn concentrations decreased up to 3 orders of magnitude at the end of $56 \mathrm{~d}$ equilibration, while [SEM - AVS] values varied only $<2 \times$. This decrease in porewater Zn concentrations was most pronounced in the sediments with higher Zn concentrations.

The combination of high metal concentrations and short metal-sediment equilibration inevitably accentuates the exposure of animals to metals in porewater, so a significant relationship might be expected between metal bioavailability or toxicity and [SEM - AVS] which largely controls porewater metal chemistry. These extreme conditions could also preclude or attenuate the role of dietary uptake of metals.

Manipulation of SEM to AVS by varying AVS concentrations allowed use of environmentally realistic metal concentrations in the present study (see also J. S. Lee et al. 2000). As found elsewhere, porewater metals were largely controlled by AVS and the pattern of the metal-AVS relationship was similar regardless of the sediment manipulation methods (J. S. Lee et al. 2000). Use of low metal concentrations would shift the partitioning of metals to the particulate phase. Consequently, uptake from ingestion of contaminated particles becomes more important. Other bioaccumulation studies (Selck et al. 1998, Wang et al. 1999) have also reported that marine polychaetes accumulate metals predominately from ingestion of particles when environmentally realistic metal concentrations were used. Studies (Ankley 1996 and references therein) evaluating AVS protocols for bioaccumulation have frequently reported that metal bioaccumulation increased linearly with spiked metal concentrations independent of [SEM - AVS]. In natural conditions, metal contaminants are introduced gradually and equilibrated with sediments over long periods. Dietary uptake of contaminated particles either from sediments or the water column is likely to play an important role in these circumstances.

Worms accumulated more metal overall, and more metal from ingested food particles, when they were exposed to supplementary, contaminated food particles. The magnitude and routes of the animals' exposure to metals were dynamically shifted as the external exposure conditions were altered. The increase in tissue metal concentrations with small additions of supplementary, contaminated food also suggested that the animals selectively fed on the supplementary 
food. This was further evidenced by observation of Neanthes arenaceodentata emerging from its burrow and feeding on supplementary food particles on the sediment surface, as seen in other studies (Pesch et al. 1987). Maloney (1996), Schaanning et al. (1996) and Lee \& Luoma (1998) demonstrated that various benthic invertebrates accumulate metals considerably more from ingestion of organic-rich food particles than organic-poor sediments. For example, Lee \& Luoma (1998) reported that assimilation efficiency of $\mathrm{Cd}, \mathrm{Cr}$ and $\mathrm{Zn}$ in the ingested particles by 2 bivalves Macoma balthica and Potamocorbula amurensis increased as the proportion of algal biomass increased. Similarly, Lutofo et al. (2000) reported that $N$. arenaceodentata bioaccumulated greater amounts of DDT when they were exposed to contaminated TetraMin ${ }^{\circledR}$ than when they were exposed to contaminated sediments only.

Bioassay protocols that use uncontaminated supplementary food, as does the growth test for Neanthes arenaceodentata, could underestimate the exposure to contaminants that animals might experience under natural conditions. In the present study, animals exposed to uncontaminated food bioaccumulated 40 to $60 \%$ less Ag and Cd than did animals exposed to food contaminated to a similar level as sediments $\left(\mathrm{F}_{1 \times}\right)$. Use of nutritious supplementary food thus introduced additional complexity to bioassays. The TetraMin ${ }^{\circledR}$ used as supplementary food in the present study was enriched with organic material (LOI $=90 \%$ at $450^{\circ} \mathrm{C}$ for $5 \mathrm{~h}$ ) and resulted in rapid growth of the test worms $(12.3 \%$ dry wt $\mathrm{d}^{-1}$ ). The rapid growth of test animals probably also diluted tissue metal concentrations and could have reduced their potential toxic effects (see also Lotufo et al. 2000). Additional tissue metal burden (content) data would be needed to evaluate total metal bioaccumulation when different growth regimes (or food quantitiy and quality) are considered.

The contribution of dissolved metals to tissue bioaccumulation was estimated with the assumption that the difference in uptake between the most oxic sediment (S1) and anoxic sediment (S5) was due to differences in dissolved metal concentrations. However, other factors such as differences in metal bioavailability from ingested sediments and changes in burrowing behavior of the worms in response to sulfide concentration changes, could also have contributed the difference in tissue metal concentrations. For example, Wang et al. (1999) reported that the deposit feeding polychaete Nereis (Neanthes) succinea assimilated Ag, Cd and Zn associated with oxic sediments up to $3 \times$ more efficiently than those from anoxic sediments. If this occurred in our experiments, the actual contribution from dissolved metals could have been less than the estimations.

\section{CONCLUSION}

The marine polychaete Neanthes arenaceodentata accumulated Ag and Cd predominately from ingestion of contaminated sediments. Addition of contaminated, supplementary food increased bioaccumulation. Dissolved metals in porewater and overlying water or AVS had a minor influence on metal bioaccumulation in the worm. Thus the magnitude and pathways of metal uptake in the worm were dynamically changed, following changes in external exposure conditions and various biological responses to such changes. A proposed sediment quality criterion for metals based on the AVS normalization approach could have limited application to situations where introduced metals have been equilibrated with sediments and where natural foods, over long periods and exposure pathways other than the dissolved source, dominate. Understanding of feeding ecology, the geochemical and biological factors affecting metal bioavailability, and evaluation of relevant uptake pathways for bioaccumulation, are prerequisites for the development of environmentally relevant sediment quality criteria for metals.

Acknowledgements. We thank Dr W. X. Wang for constructive review and Dr D. J. Reish for supplying the polychaetes. This work was partly supported by the Toxic Substances Hydrology Program and the National Research Program of USGS. J.-S.L. and H.Y. were supported in part by a grant from the Ministry of Science and Technology, Korea (KISTEP: SMETBIOS 98-2000-N11-04-01-A-01).

\section{LITERATURE CITED}

Anderson BS, Hunt JW, Phillips BM, Tudor S, Fairey R, Newman J, Puckett HM, Stephenson M, Long ER, Tjeerdema RS (1998) Comparison of marine sediment toxicity test protocols for the amphipod Repoxynius abronius and the polychaete worm Nereis (Neanthes) arenaceodentata. Environ Toxicol Chem 17:859-866

Ankley GT (1996) Evaluation of metal/acid-volatile 5sulfide relationship in the prediction of metal bioaccumulation by benthic macroinvertebrates. Environ Toxicol Chem 15: 2138-2146

Ankley GT, Di Toro DM, Hansen DJ, Berry WJ (1996) Technical basis and proposal for deriving sediment quality criteria for metals. Environ Toxicol Chem 15:2056-2066

Arifin Z, Bendall-Young LI (1997) Feeding response and carbon assimilation by the blue mussel Mutilus trossulus exposed to environmentally relevant seston matrices. Mar Ecol Prog Ser 160:241-253

Bayne BL, Iglesias JIP, Hawkins AJS, Navarro E, Heral M, Deslous-Paoli JM (1993) Feeding behavior of the mussel Mytilus edulis: responses to variations in quantity and organic content of the seston. J Mar Biol Assoc UK 73: 813-829

Berry WJ, Hansen DJ, Mahony JD, Robson DL, Di Toro DM, Shipley BP, Rogers B, Corbin JM, Boothman WS (1996) Predicting the toxicity of metal-spiked laboratory sedi- 
ments using acid-volatile sulfide and interstitial water normalizations. Environ Toxicol Chem 15:2067-2079

Berry WJ, Cantwell MG, Edwards PA, Serbst JR, Hansen DJ (1999) Predicting toxicity of sediments spiked with silver. Environ Toxicol Chem 18:40-48

Bourg ACM (1987) Trace metal adsorption modeling and particle-water interaction in estuarine environments. Cont Shelf Res 7:1319-1332

Brown CL, Luoma SN (1995) Use of the euryhaline bivalve Potamocorbula amurensis as a biosentinel species to assess trace metal contamination in San Francisco Bay. Mar Ecol Prog Ser 124:129-142

Bryan GW, Langston WJ (1992) Bioavailability, accumulation and effects of heavy metals in sediments with special reference to United Kingdom estuaries: a review. Environ Pollut 76:89-131

Cain DJ, Luoma SN (1990) Influence of seasonal growth, age, and environmental exposure on $\mathrm{Cu}$ and $\mathrm{Ag}$ in a bivalve indicator, Macoma balthica, in San Francisco Bay. Mar Ecol Prog Ser 60:45-55

DeWitt TH, Swartz RC, Hansen DJ, McGovern D, Berry WJ (1996) Bioavailability and chronic toxicity of cadmium in sediment to the estuarine amphipod Leptocheirus plumulosus. Environ Toxicol Chem 15:2095-2101

Dillon TM, Moore DW, Gibson AB (1993) Development of a chronic sublethal bioassay for evaluation contaminated sediment with the marine polychaete worm Nereis (Neanthes) arenaceodentata. Environ Toxicol Chem 12:589-605

Di Toro DM, Mahony JD, Hansen DJ, Scott KJ, Hicks MB Mayr SM, Redmond MS (1990) Toxicity of cadmium in sediments: the role of acid volatile sulfide. Environ Toxicol Chem 9:1489-1504

Di Toro DM, Mahony JD, Hansen DJ, Berry WJ (1996) A model of the oxidation of iron and cadmium sulfide in sediments. Environ Toxicol Chem 15:2168-2186

Folk RL (1954) The distribution between grain size and mineral composition in sedimentary rock nomenclature. J Geol 62:334-359

Hare L, Carignan R, Huerta-Diaz MA (1994) A field study of metal toxicity and accumulation by benthic invertebrates: implication for the acid-volatile sulfide (AVS) model. Limnol Oceanogr 39:1653-1668

Hassan SM, Garrison AW, Allen HE, Di Toro DM, Ankley GT (1996) Estimation of partition coefficients for five trace metals in sandy sediments and application to sediment quality criteria. Environ Toxicol Chem 15:2198-2208

Hornberger MI, Luoma SN, Cain DJ, Parchaso F, Brown CL, Bouse RM, Wellise C, Thomson JK (2000) Linkage of bioaccumulation and biological effects to changes in pollutants loads in south San Francisco Bay. Environ Sci Technol 34:2401-2409

John DM, Ginn TC, Reish DJ (1990) Protocol for juvenile $N$. arenaceodentata sediment bioassay. EPA 68-D8-0085. US Environ Prot Agency, Seattle, WA

Kemp PF, Swartz RC (1988) Acute toxicity of interstitial and particle-bound cadmium to a marine infaunal amphipod. Mar Environ Res 26:135-153

Lee BG, Luoma SN (1998) Influence of microalgal biomass on absorption efficiency of $\mathrm{Cd}, \mathrm{Cr}$, and $\mathrm{Zn}$ by two bivalves from San Francisco Bay. Limnol Oceanogr 43: 1455-1466

Lee BG, Griscom SB, Lee JS, Choi HJ, Koh CH, Luoma SN, Fisher NS (2000a) Influences of dietary uptake and reactive sulfides on metal bioavailability from aquatic sediments. Science 287:282-284

Lee BG, Lee JS, Luoma SN, Choi HJ, Koh CH (2000b) Influence of acid-volatile sulfide and metal concentrations on metal bioavailability to marine invertebrates in contaminated sediments. Environ Sci Technol 34:4517-4523

Lee JS, Lee BG, Luoma SN, Choi HJ, Koh CH, Brown CL (2000) Influence of acid-volatile sulfides and metal concentrations on metal partitioning in contaminated sediments. Environ Sci Technol 34:4511-4516

Leonard EN, Mount DR, Ankley GT (1999) Modification of metal partitioning by supplementing acid volatile sulfide in freshwater sediments. Environ Toxicol Chem 18: 858-864

Liber K, Call DJ, Markee TP, Schmude KL, Balcer MD, Whiteman FW, Ankley GT (1996) Effects of acid-volatile sulfide on zinc bioavailablity and toxicity to benthic macroinvertebrates: a spiked-sediment field experiment. Environ Toxicol Chem 15:2113-2125

Long ER, MacDonald DD, Smith SL, Calder FD (1995) Incidence of adverse biological effects within ranges of chemical concentrations in marine and estuarine sediments. Environ Manage 19:81-97

Luoma SN, Bryan GW (1982) A statistical study of environmental factors controlling concentrations of heavy metals in the burrowing bivalve Scrobicularia plana and the polychaete Nereis diversicolor. Estuar Coast Shelf Sci 15:95-108

Luoma SN, Fisher NS (1997) Uncertainties in assessing contaminant exposure from sediments. In: Ingersoll CG, Dillon T, Biddinger GR (eds) Ecological risk assessment of contaminated sediments. SETAC Press, Pensacola, FL, p 211-237

Luoma SN, Johns C, Fisher NS, Steinberg NA, Oremland RS, Reinfelder JR (1992) Determination of selenium bioavailability to a benthic bivalve from particulate and solute pathways. Eviron Sci Technol 26:485-491

Lutofo GR, Farrar JD, Bridges TS (2000) Effects of exposure source, worm density, and sex on DDT bioaccumulation and toxicity in the marine polychaete Neanthes arenaceodentata. Environ Toxicol Chem 19:472-484

Maloney J (1996) Influence of organic enrichment on the partitioning and bioavailability of cadmium in a microcosm study. Mar Ecol Prog Ser 144:147-161

Mason AZ, Jenkins KD, Sullivan PA (1988) Mechanisms of trace metal accumulation in the polychaete Neanthes arenaceodentata. J Mar Biol Assoc UK 68:61-80

Morse JW, Millero FJ, Cornwell JC, Rickard D (1987) The chemistry of the hydrogen sulfide and iron sulfide systems in natural waters. Earth-Sci Rev 24:1-42

Munger C, Hare L (1997) Relative importance of water and food as cadmium sources to an aquatic insect (Chaoborus punctipennis): implications for predicting Cd bioaccumulation in nature. Environ Sci Technol 31:891-895

Murdoch MH, Chapman PM, Johns M, Paine MD (1997) Chronic effects on organochlorine exposure in sediment to the marine polychaete Neanthes arenaceodentata. Environ Toxicol Chem 16:1494-1503

Pesch CE, Zajac RN, Whitlatch RB, Balboni MA (1987) Effect of intraspecific density on life history traits and population growth rate of Neanthes arenaceodentata (Polychaeta: Nereidae) in the laboratory. Mar Biol 96:545-554

Pesch CE, Hansen DJ, Boothman WS, Berry WJ, Mahony JD (1995) The role of acid-volatile sulfide and interstitial water metal concentrations in determining bioavailability of cadmium and nickel from contaminated sediments to the marine polychaete Neanthes arenaceodentata. Environ Toxicol Chem 14:129-141

Reish DJ (1980) Use of plychaetous annelids as test organisms for marine bioassay experiments. ASTM Spec Tech Publ 715:140-154

Reish DJ (1985) The use of the polychaetous annelid Nean- 
thes arenaceodentata as a laboratory experimental animal. Tethys 11:335-341

Schaanning MT, Hylland K, Eriksen DO, Bergan TD (1996) Interactions between eutrophication and contamination. II. Mobilization and bioaccumulation of $\mathrm{Hg}$ and $\mathrm{Cd}$ from marine sediments. Mar Pollut Bull 33:71-79

Selck H, Forbes VE, Forbes TL (1998) Toxicity and toxicokinetics of cadmium in Capitella sp. I: relative importance of water and sediment as routes of cadmium uptake. Mar Ecol Prog Ser 164:167-178

Sibley PK, Ankley GT, Cotter AM, Leonard EN (1996) Predicting chronic toxicity of sediments spiked with zinc: an evaluation of the acid-volatile sulfide model using a life-

Editorial responsibility: Otto Kinne (Editor), Oldendorf/Luhe, Germany cycle test with the midge Chironomus tentans. Environ Toxicol Chem 15:2102-2112

Wang WX, Fisher NS, Luoma SN (1996) Kinetic determination of trace element bioaccumulation in the mussel Mytilus edulis. Mar Ecol Prog Ser 140:91-113

Wang WX, Stupakoff I, Fisher NS (1999) Bioavailability of dissolved and sediment-bound metals to a marine depositfeeding polychaete. Mar Ecol Prog Ser 178:281-293

Warren LA, Tessier A, Hare L (1998) Modeling cadmium accumulation by benthic invertebrates in situ: the relative contributions of sediment and overlying water reservoirs to organism cadmium concentrations. Limnol Oceanogr 43:1442-1454

Submitted: May 16, 2000; Accepted: October 17, 2000 Proofs received from author(s): June 21, 2001 